\title{
CEACAM7 wt Allele
}

National Cancer Institute

\section{Source}

National Cancer Institute. CEACAM7 wt Allele. NCI Thesaurus. Code C51025.

Human CEACAM7 wild-type allele is located in the vicinity of 19q13.2 and is approximately $15 \mathrm{~kb}$ in length. This allele, which encodes carcinoembryonic antig en-related cell adhesion molecule 7 protein, is involved in tumor suppression and cellular growth. 